This manuscript is contextually identical with the following published paper:

Avar, P., Zrínyi, Z., Maász, G., Takátsy, A., Lovas, S., G.-Tóth, L., Pirger, Z. (2016) $\beta$-Estradiol and ethinyl-estradiol contamination in the rivers of the Carpathian Basin. Environmental Science and Pollution Research 23(12) pp. 11630-11638.

DOI: $10.1007 / \mathrm{s} 11356-016-6276-2$

The original published pdf available in this website:

http://link.springer.com/article/10.1007\%2Fs11356-016-6276-2

\title{
$\beta$-estradiol and ethinyl-estradiol contamination in the rivers of the Carpathian Basin
}

\author{
Péter Avar ${ }^{a^{*}}$, Zita Zrínyi ${ }^{b}$, Gábor Maász ${ }^{\mathrm{a}, \mathrm{b}}$, Anikó Takátsy ${ }^{\mathrm{a}}$, Sándor Lovas ${ }^{\mathrm{b}}$, Lászlo G.-Tóth ${ }^{\mathrm{c}}$, Zsolt \\ Pirger ${ }^{\mathrm{b}}$ \\ ${ }^{a}$ Department of Analytical Biochemistry, Institute of Biochemistry and Medical Chemistry, University of \\ Pécs, Pécs, H-7624, Hungary; ${ }^{b}$ Adaptive Neuroethology, Department of Experimental Zoology and \\ ${ }^{c}$ Department of Hydrozoology, Balaton Limnological Institute, MTA Centre for Ecological Research, \\ Tihany, $\mathrm{H}$-8237, Hungary
}

*Corresponding author: peter.avar@aok.pte.hu, 0036-72-536-000/31659

Keywords: $\beta$-estradiol, ethinyl estradiol, freshwater, river, estrogen, steroid

\begin{abstract}
$17 \beta$-estradiol (E2) and 17 -ethinyl estradiol (EE2), which are environmental estrogens have been determined with LC-MS in freshwater. Their sensitive analysis needs derivatisation and therefore is very hard to achieve in multiresidue screening. We analysed samples from all the large and some small rivers (River Danube, Drava, Mur, Sava, Tisza and Zala) of the Carpathian Basin and from Lake Balaton. Freshwater was extracted on solid phase and derivatised using dansyl-chloride. Separation was performed on a Kinetex XB-C18 column. Detection was achieved with a benchtop orbitrap mass spectrometer using targeted MS analysis for quantification. Limits of quantification were $0.05 \mathrm{ng} / \mathrm{L}$ (MS1) and $0.1 \mathrm{ng} / \mathrm{L}(\mathrm{MS} / \mathrm{MS})$ for E2, and $0.001 \mathrm{ng} / \mathrm{L}$ (MS1) and $0.2 \mathrm{ng} / \mathrm{L}$ (MS/MS) for EE2. River samples contained n.d.-5.2 ng/L E2 and n.d.-0.68 ng/L EE2. Average levels of E2 and EE2 were 0.61 and $0.084 \mathrm{ng} / \mathrm{L}$ respectively in rivers, water courses and Lake Balaton together, but not counting city canal water. EE2 was less abundant, but it was still present in almost all of the samples. In beach water samples from Lake Balaton we measured 0.076-0.233 E2 and n.d.-0.133 EE2. A relative high amount of EE2 was found in river Zala $(0.68 \mathrm{ng} / \mathrm{L})$ and in Hévíz-Páhoki canal $(0.52 \mathrm{ng} / \mathrm{L})$, which are both in the catchment area of Lake Balaton (Hungary).
\end{abstract}

Highlights

Method is proposed for simultaneous determination of $17 \beta$-estradiol and $17 \alpha$-ethinyl estradiol.

Derivatization is necessary to reach low LOQ.

Low $\mathrm{ng} / \mathrm{L}$ presence of estrogens in selected European Rivers has been detected.

\section{Introduction}

Hormones with estrogenic functions are subjects of intensive research continuously. $\beta$-estradiol (E2) is an endogenous steroid hormone present in both human and animal tissues and body liquids (James 2011, Ketha et al. 2015). E2 is the most potent natural estrogen. Ethinyl estradiol (EE2) is a synthetic analogue of E2 and it has an intensive human therapeutic usage. EE2 is a component in many frequently used contraceptives (Robles 2010, Shinichi Miyagawa 2016). Domestic effluents and livestock waste excrete a considerable amount of hormones in addition to agriculture runoffs and industrial sources. The excreted urine contains a large part of the hormones in the form of sulfate and glucuronide conjugates, but the bacterium Escherichia coli in wastewater is able to deconjugate these metabolites due to its $\beta$-glucuronidase and sulfatase activity (Aris et al. 2014, Costa et al. 2010). E2, EE2 and their water soluble sulfate and glucuronide metabolites enter natural streams, rivers, lakes mainly through cleaned wastewater. There are feasible cleaning methods for these compounds, but the generally used three step cleaning method in waste water treatment plants cannot eliminate them 
totally (Kim et al. 2015). Consequently, an unquantified load of estrogens is released into the aquatic environment, where it can be absorbed by sediment and persists for long periods or it is taken up by aquatic biota (Matozzo et al. 2008). E2 is principally a vertebrate hormone, although it was detected in some invertebrates, such as molluscs. Many aquatic species express estrogene receptors. Some species are known to have mechanisms, which allow them to maintain their endogenous hormonal levels in the case of exogenous E2 exposure (Janer et al. 2005), but a wide range of species are very sensitive to steroid contaminants (Bhandari et al. 2015, Huang et al. 2015). Bioaccumulation and biotransformation of xenoestrogens, their effects on individual development and alterations in adult behaviours have been reported earlier (Bhandari et al. 2015, Huang et al. 2015, Liu et al. 2011a, Yan et al. 2012). Increased hepatic-somatic index and decreased gonadosomatic index have been described in E2 and EE2 treated fishes. That suggests that molecular changes appear in the whole body of treated fishes. Changes are described in the liver, kidneys, and in the brain of two species; in silver catfish (Bagrus filamentosus) and in zebrafish (Danio rerio) (Costa et al. 2010, Martyniuk et al. 2007). The immune system and the mortality of leucocytes of fishes can also be affected (Bado-Nilles et al. 2014). The most used indicator of exposure of exogenous estrogens in aquatic species is plasma vitellogenin. EE2 induces vitellogenin production and affects anxiety and shoaling behavior in adult male zebrafish (Reyhanian et al. 2011) and induces anxiogenic behavior in guppies (Poecilia reticulata) (Hallgren et al. 2011). The exposure to mixtures of E2 and EE2 effects sperm motility, fertilization, embryo, - and larval survival even at relevant environmental concentrations in prejerrey fish (Odontesthes bonariensis) (Garriz et al. 2015). Bioaccumulations of E2 and EE2, their effects on individual development, and alterations in behaviors have also been reported. (Bhandari et al. 2015, Huang et al. 2015, Yan et al. 2012).

Considering their diverse role in the regulation of endogenous processes, quantitation of these two chemicals is very useful not only in the clinical assessment but also in environmental investigations (Aris et al. 2014). In the European Union pharmaceuticals authorization procedures include Comission directives, which contain a requirement to develop a strategic approach to the pollution of water by pharmaceutical substances. E2 and EE2 were newly added to the EU watch list of emerging pollutants in 2013 (Directive 2013/39/EU) (European Parliament 2013). They were also included in EU Commission Implementing Decision 2015/495 (European Parliament 2015) in which a watch list of substances has been established for Union-wide monitoring in the field of water policy pursuant to earlier Directive 2008/105/EC (European Parliament 2008). Pharmaceuticals on the watch list are not on the EU priority list of environmental pollutants, but they can be added to it in the future.

There are several ways to analyze these pollutants (LaFleur \&Schug 2011). Depending on the aim of the study and their opportunities analysts use GC-MS (Liu et al. 2009), LC-MS (Abhishek Gandhi 2015, Ke et al. 2014, Skotnicka-Pitak et al. 2008) and immunoassays (Franke et al. 2011, Moraes et al. 2015, Tan \&Wei 2015), but chromatographic based methods with UV-VIS, fluorescence or electrochemical detection are also available (Popescu et al. 2008, Xu et al. 2013, Zou et al. 2014). Estrogenic activity can be determined by biological monitoring approaches. There are in situ and in vivo bioassays, which can be used as screening methods to estimate total estrogenic activity of mixtures of compounds that act through the same mode of action. In vitro assays are also available and broadly used to evaluate the estrogenic activity in wastewater or other water samples (Jarosova et al. 2014). In the field of environmental analysis and especially in the case of E2 and EE2 mass spectrometric methods with derivatisation are considered to be the most sensitive and specific methods. MS methods measuring E2 or EE2 without derivatisation can rather be applied in the clinical assessment only, where samples contain high concentrations, and are difficult to use in environmental studies. Full MS and targeted MS/MS methods without derivatization, which are generally used in environmental monitoring applications, detect 40-100 or even more target compounds. These screening methods however often do not include or cannot detect E2 and EE2 due to poor detection limits (Chitescu et al. 2015, Kuster et al. 2008, Liu et al. 2011b, Loos et al. 2010). Evaluation of derivatives of estrogens makes positive mode electrospray ionization (ESI) mass spectrometric detection possible and improves generally the sensitivity of MS methods (Anari et al. 2002, Xu \&Spink 2008). A novel comparison of several derivatisation methods for the determination of E2 using standard solutions was recently published (Li \&Franke 2015). We applied dansyl chloride (DSCl) derivatisation in our method because it was found to be very sensitive and $\mathrm{DSCl}$ is approximately 10 fold cheaper than 1-methylimidazole-2-sulfonyl chloride, which produced the lowest limit of detection in the comparison. Our own chromatographic method with mass spectrometric detection has been developed and it was applied in the field of environmental analysis. We collected samples in Slovenia and in Hungary, from Lake Balaton, from six Central-European river (Danube, Drava, Mur, Sava, Tisza and Zala), from smaller watercourses and from a city canal in the urbanized area of the city of Pécs. (Suppl. Fig. 1) In order to provide supplementary information of our methodology, results have been 
quantified and are presented both based only on MS1 peak areas and from peak areas of MS/MS transitions also. Measured concentrations in the text are MS1 values, results of MS/MS processing are presented in the tables (Table 1 and Table 2) only.

1.1 Rationale and aims

Our aim was to develop a specific and selective LC-MS method for the determination of the most potent natural estrogen, E2, and the probably most used synthetic estrogen, EE2. We were also determined to measure these endocrine disrupting compounds (EDCs) in Lake Balaton and in Central European rivers, because there is very limited data published about the occurrence of EE2 in the Carpathian basin (Aris et al. 2014). As EDCs in waters can not only occur in dissolved form (Andrasi et al. 2013, Faludi et al. 2015), but associate with suspended particles also, we decided to measure the dissolved and suspended phases separately as well. In order investigate this phenomenon we have chosen an urban canal water sample and several freshwater samples and measured separately the estrogen content of their suspended and dissolved phase.

\section{Experimental}

\subsection{Materials and standards}

Estrogen standards (E2, EE2) and acetone (HPLC grade) were purchased from Sigma-Aldrich (Budapest, Hungary). Acetonitrile, distilled water and methanol were of LC-MS grade, all ordered from VWR (Debrecen, Hungary). Formic acid was obtained from LGC Standards (Wesel, Germany). TertButyl methyl ether (TBME), HPLC grade was purchased from Scharlab (Debrecen, Hungary). Glass microfiber filters $(45 \mu \mathrm{m})$ were obtained from Whatman (Maidstone, UK). Strata C18-E SPE cartridges $(55 \mu \mathrm{m}, 70 \AA)$ were ordered from GenLab (Budapest, Hungary).

2.2 Stock and calibration standard solutions

Standard solutions were prepared by weighing and dissolving one estrogen at a time in methanol. Calibration standards were derivatised at eight concentration level covering the range from 0.001 $\mu \mathrm{g} / \mathrm{mL}$ to $0.1 \mu \mathrm{g} / \mathrm{mL}$ ). Dansyl derivatisation was carried out with $100 \mu \mathrm{L}$ from each standard solution similarly to water samples.

2.3 Sample preparation

River and canal surface waters were collected in glass bottles and stored at $4{ }^{\circ} \mathrm{C}$ in the dark, no longer than 24 hours before being processed. Pécsi víz canal water was filtrated on glass microfiber filter before solid phase extraction. The rest of the samples were not filtrated.

2.4 Solid phase extraction

Solid phase extraction was carried out according to our previous method for progestogens with small modifications (Avar et al. 2015). SPE cartridges were conditioned with $15 \mathrm{~mL}$ methanol and equilibrated with $20 \mathrm{~mL}$ LC-MS grade water. Then $1000 \mathrm{~mL}$ sample was loaded, the cartridge was washed with $20 \mathrm{~mL}$ LC-MS grade water and analytes were eluted with $15 \mathrm{~mL}$ methanol. Eluted samples were concentrated to dryness first with rotary evaporator at $35^{\circ} \mathrm{C}$, than they were dissolved in methanol $\left(3^{*} 200 \mu \mathrm{L}\right)$, transferred to Eppendorf tubes and concentrated again with an Eppendorf Concentrator Plus $\left(30^{\circ} \mathrm{C}, \mathrm{V}-\mathrm{AL}\right.$ mode). In the case of Pécsi víz canal water only $500 \mathrm{~mL}$ was extracted.

2.5 Extraction of suspended phase

The filtrate was collected from $500 \mathrm{~mL}$ Pécsi víz canal water (PV in the tables) or from $1000 \mathrm{~mL}$ rivers water samples (B1, D1, D5 and MU) on Whatman glass microfiber filters. Filters were dried and extracted with $15 \mathrm{~mL}$ TBME three times. Solvent was evaporated (rotary evaporator $35^{\circ} \mathrm{C}$ ) and residue was reconstituted in $100 \mu \mathrm{L}$ methanol.

2.6 Derivatisation

Dried extracts of samples and standards diluted to known concentrations and dried also, were used for derivatisation. $50 \mu \mathrm{L} 0.2 \mathrm{M}$ sodium bicarbonate (in LC-MS grade water) and $50 \mu \mathrm{L} 1 \mathrm{mg} / \mathrm{mL}$ dansyl chloride (in acetone) were added to each of them. These mixtures were incubated in a thermomixer $\left(65^{\circ} \mathrm{C}, 300 \mathrm{rpm}\right)$ for 10 minutes. Then they were cooled down on ice (2 minutes) and transferred to the autosampler of the HPLC, which was kept at $4^{\circ} \mathrm{C}$. Dansyl-chloride can react with the hydroxyl groups $(3-\mathrm{OH}, 17-\mathrm{OH})$ of E2/EE2 forming quinoneimins or urethans. The $\mathrm{m} / \mathrm{z}$ value of E2-DS and EE2-DS is independent of the position of dansyl-derivatization, but the nucleophilic substitution of the phenolic hydroxyl group is privileged due to the electron withdrawing effect of the aromatic ring (Fig. 1). The introduction of the basic nitrogen containing group to the estrogen molecule (E2, EE2) enhances positive mode ionization under acidic conditions through decreasing $\mathrm{pK}_{\mathrm{a}}$ of the $3-\mathrm{OH}$ (after derivatization: 3-O-dansyl) group. 


\subsection{HPLC-MS analysis}

HPLC-MS was carried out on a Q-Exactive orbitrap mass spectrometer coupled with a Dionex Ultimate 3000 UHPLC (Thermo Fisher Scientific, Bremen, Germany). 10 uL was injected three times of each derivatised sample. Liquid chromatographic separation was performed on a Kinetex 2.6u XBC18 $100 \AA$ HPLC column $(150 \times 2.1 \mathrm{~mm})$ maintained at $30^{\circ} \mathrm{C}$. The mobile phase consisted of solvent $A$ $(0.01 \% \mathrm{v} / \mathrm{v}$ formic acid in water) and solvent $\mathrm{B}(0.01 \% \mathrm{v} / \mathrm{v}$ formic acid in acetonitrile). Flow rate was set to $400 \mu \mathrm{L} / \mathrm{min}$. The initial composition contained $10 \% \mathrm{~B}$ and it was kept constant for 1 minute. Percentage of eluent B was raised to 25 in 2 minutes. Then it was raised further to $70 \%$ in 2 minutes, then to $75 \%$ in 10 minutes. After that the column was washed and equilibrated for 15 minutes. The chromatographic peak of E2 was observed at 13.09-13.17 min, EE2 was eluted at 13.66-13.73 min (Fig. 2 and 3).

Mass detection was carried out in positive mode. Spray voltage in the heated electrospray ion source was set to $4.0 \mathrm{kV}$ Capillary temperature was set to $380^{\circ} \mathrm{C}$, while the probe heater temperature was $300^{\circ} \mathrm{C}$. RF of the S-lenses was set to 60 . Sheath and auxiliary gas flow rates were set to 60 and 20 arbitrary units respectively. No sweep gas was applied. The energy in the higher-energy collisional induced dissociation (HCD) cell was set to $50 \%$ by E2 and $49 \%$ by EE2. Automatic gain control was set to $1 \mathrm{e} 6$ by MS1 and 2e5 by MS2 scans. tSIM scan ranges were $506.0-506.5$ and $530.0-530.5 \mathrm{~m} / \mathrm{z}$. By targeted-MS2 scans we applied an $0.4 \mathrm{~m} / \mathrm{z}$ isolation window and 506.24-171.10 (E2) and 530.24171.10 (EE2) transitions $(\mathrm{m} / \mathrm{z}$ ) have been used.

\section{Results}

\subsection{Standard curves, limits of quantification}

Linear standard curves were obtained using Thermo Excalibur Quan Browser. Response was measured in area and weighting was set to equal. Correlation coefficients $\left(R^{2}\right)$ of calibration curves were 0.9774 (MS1) and 0.9712 (MS2) by E2, and 0.9952 (MS1) and 0.9980 (MS2) by EE2. Limits of quantification (Signal to Noise $=10$ ) were determined from standard solutions and found $0.05 \mathrm{ng} / \mathrm{L}$ (MS1) and $0.1 \mathrm{ng} / \mathrm{L}$ (MS2) by E2, and $0.001 \mathrm{ng} / \mathrm{L}$ (MS1) and $0.2 \mathrm{ng} / \mathrm{L}$ (MS2) by EE2. To have a comparison limit of quantifications (LOQ) have been measured in negative mode, without derivatization also. By these experiments instrument settings have only been adjusted but not optimized. LOQ for E2 (detected as $\mathrm{m} / \mathrm{z} 255.23$ ) (Koal et al. 2012) was found $7.5 \mu \mathrm{g} / \mathrm{L}$. LOQ for EE2 detected as $\mathrm{m} / \mathrm{z} 295.16$ (MS1) was $20 \mathrm{ng} / \mathrm{L}$. In the case of EE2 adduct formation with formic acid was observed (m/z 341.17), LOQ $500 \mathrm{ng} / \mathrm{L}$.

3.2 Selectivity, reproducibility and matrix effect

Selectivity and matrix effect were tested comparing spiked and not spiked samples. No shift in the retention time could be observed. Recoveries were measured from spiked freshwater samples. 1000 $\mathrm{mL}$ was spiked with various amounts. Recoveries were between 75 and 95 percent. (Suppl. Table 1.). Blank chromatograms were achieved from $1000 \mathrm{~mL}$ LC-MS grade water. It was subjected to the same procedures (solid phase extraction and derivatisation) as real samples (Suppl. Fig. 2). Intra-day and inter-day reproducibility was tested with $1000 \mathrm{ml}$ spiked LC-MS grade water. The coefficients of variation were 6.04-9.94 (Suppl. Table 2.).

3.3 Measured concentrations

Both E2 and EE2 were found in river samples. EE2 was less abundant than E2, but it was also present in almost all of the samples. N.d.-5.2 ng/L E2 (Table 1) and n.d.-0.68 ng/L EE2 (Table 2) were measured. A relative high amount of EE2 was found in River Zala $(0.68 \mathrm{ng} / \mathrm{L})$ and in Hévíz-Páhoki canal $(0.52 \mathrm{ng} / \mathrm{L})$, which are both in the catchment area of Lake Balaton. The presence of E2 could be confirmed with MS/MS transitions in 12 out of 23 samples. The presence of EE2, due to poor $(0.2 \mathrm{ng} / \mathrm{L})$ LOQ value, could only be confirmed with MS/MS transitions at two sampling sites (Hévíz-Páhoki canal; HP and River Zala; ZA). In Pécsi víz city canal sample we determined, that one quarter of the total E2, but only $2 \%$ of the total EE2 was in the suspended phase. That suggests a higher importance of the analysis of the dissolved phase by both analytes.

\section{Discussion}

Due to the intensive use and high demand of estrogens the occurrence of E2 and EE2 in natural waters is a major concern. According to data published between 2003 and 2013 scientists found more than $1 \mathrm{ng} / \mathrm{L} \mathrm{E2}$ at least at one of their sampling sites in 13 out of 18 freshwater investigations worldwide. EE2 could be detected over $1 \mathrm{nG} / \mathrm{L}$ with a 50\% chance (Aris et al. 2014). No detectable amount of E2 and EE2 were found in surface waters at the Mediterranean Spanish coast (with LOD 
0.06 and $0.02 \mathrm{ng} / \mathrm{L}$, respectively) (Ripolles et al. 2014). Neither E2 nor EE2 could be found in River Tiber and River Aniene (Italy, LODs: 10ng/L) (Patrolecco et al. 2015). In Dutch surface waters both analytes were detected mostly under the limit of quantification $(<0.1 \mathrm{ng} / \mathrm{L})$ (Belfroid et al. 1999). In river samples in the Paris area (France) 1.4 to 3.0 mean E2 and 1.1 to 2.9 mean EE2 was found (Cargouet et al. 2004). Hungarian scientists reported contamination in the River Danube earlier. In 2009 E2 was found neither in local WWTP effluents nor in River Danube (LOD: 8.6ng/L) (Sebok et al. 2009), but there were 0-0.4 ng/L E2 and 0-1.16 ng/L EE2 found at nearby locations in 2010. This later study used derivatization in order to improve sensitivity (LODs not available) and the occurrence in the suspended phase was also studied. In that phase of Danube water $0.46 \mathrm{ng} / \mathrm{L}$ EE2 and no E2 was detected. (Andrasi et al. 2013). Changing amount of E2 (low ng/L, only graphical data available) and no EE2 was detected in the Yangtze Estuary (China), where their occurrence was followed over four seasons (Nie et al. 2015). In rivers of the UK $1 \mathrm{ng} / \mathrm{L}$ to almost $50 \mathrm{ng} / \mathrm{L}$ E2 was measured and EE2 could also be detected, but not quantified (Desbrow et al. 1998). Later, in 2003 in River Nene and River Lea (UK) $0.9 \mathrm{ng} / \mathrm{L}$ mean E2 and $0.7 \mathrm{ng} / \mathrm{L}$ mean EE2 were measured (Williams et al. 2003). 0.15 to $3.6 \mathrm{ng} / \mathrm{L} \mathrm{E2}$ and 0.1 to $5.1 \mathrm{ng} / \mathrm{L}$ EE2 were found in German rivers in 2001 (Kuch \&Ballschmiter 2001). In 2010 $1.1 \mathrm{ng} / \mathrm{L}$ mean E2 and no EE2 (LOD: $0.14 \mathrm{ng} / \mathrm{L}$ ) were found in the Ebro basin on the lberian Peninsula (Gorga et al. 2013). High concentrations have been found in the Klang Valley in Malaysia (average E2: $20 \mathrm{ng} / \mathrm{L}$ ) (Ismail Ahmad 2007), in Venice lagoon (175 ng/L E2 and $34 \mathrm{ng} / \mathrm{L}$ EE2) (Pojana et al. 2007) and in the Piracicaba River in Brasil (137 and $194 \mathrm{ng} / \mathrm{L}$ ) (Torres et al. 2015).

EU regulation has put these compounds to the watch list of emerging pollutants two years ago, and this year (2015) maximum acceptable method detection limits have been established for them. These limits are $0.035 \mathrm{ng} / \mathrm{L}$ for EE2 and $0.4 \mathrm{ng} / \mathrm{L}$ for E2 (European Parliament 2015). These contaminants in an average equipped laboratory using multiresidue analysis without derivatization can only be determined with poor LOQ values (Liu et al. 2011b, Loos et al. 2010, Ripolles et al. 2014). Our methodology with dansyl derivatization is cheap, quick and simple enough to be considered for use in monitoring studies in the future. The use of 1-methylimidazole-2-sulfonyl adducts may be another possibility, but it must be tested (Li\&Franke 2015). Compared to the international dataset; E2 and EE2 contamination in rivers of the Carpathian basin is generally moderate. In our opinion EE2 contamination could significantly affect the endocrine systems of aquatic species over the concentration of $1 \mathrm{ng} / \mathrm{L}$ (Aris et al. 2014, Robinson \&Hellou 2009). Considering the in vivo activity of E2; environmental risk limit should be defined approximately over $10 \mathrm{ng} / \mathrm{L}$. If we accept these limits, even the concentrations measured in rivers at capital cities $(3.0 \mathrm{ng} / \mathrm{L} \mathrm{E2}$ and $0.1 \mathrm{ng} / \mathrm{L}$ EE2 at Budapest and $5.2 \mathrm{ng} / \mathrm{L}$ E2 at Ljubljana) seem to be tolerable. Though it must be taken into account that very limited data is available, that concentrations can raise dramatically if passage flow decreases and that most toxicological experiments are achieved during a few weeks or months, thus long term effects are very hard to discover. Furthermore this low level presence of E2 and EE2 in natural waters is just a small contribution to the overall estrogenicity of waters (Wise et al. 2011), which at its actual level can cause local problems in the wildlife but probably means minimal risk to public's health.

\section{Acknowledgements}

This work was supported by the state of Hungary under Grant [OTKA PD-109099].

\section{References}

Abhishek G, Swati G, Priti T (2015): High-sensitivity simultaneous liquid chromatography-tandem mass spectrometry assay of ethinyl estradiol and levonorgestrel in human plasma. Journal of Pharmaceutical Analysis 5, 316-326

Anari MR, Bakhtiar R, Zhu B, Huskey S, Franklin RB, Evans DC (2002): Derivatization of ethinylestradiol with dansyl chloride to enhance electrospray ionization: application in trace analysis of ethinylestradiol in rhesus monkey plasma. Analytical chemistry 74, 4136-44 
Andrasi N, Molnar B, Dobos B, Vasanits-Zsigrai A, Zaray G, Molnar-Perl I (2013): Determination of steroids in the dissolved and in the suspended phases of wastewater and Danube River samples by gas chromatography, tandem mass spectrometry. Talanta $115,367-373$

Aris AZ, Shamsuddin AS, Praveena SM (2014): Occurrence of 17 alpha-ethynylestradiol (EE2) in the environment and effect on exposed biota: a review. Environment international 69, 104-119

Avar P, Maasz G, Takacs P, Lovas S, Zrinyi Z, Svigruha R, Takatsy A, Toth LG, Pirger Z (2015): HPLC-MS/MS analysis of steroid hormones in environmental water samples. Drug testing and analysis doi: $10.1002 / \mathrm{dta} .1829$

Bado-Nilles A, Techer R, Porcher JM, Geffard A, Gagnaire B, Betoulle S, Sanchez W (2014): Detection of immunotoxic effects of estrogenic and androgenic endocrine disrupting compounds using splenic immune cells of the female three-spined stickleback, Gasterosteus aculeatus (L.). Environ Toxicol Phar 38, 672-683

Belfroid AC, Van der Horst A, Vethaak AD, Schafer AJ, Rijs GBJ, Wegener J, Cofino WP (1999): Analysis and occurrence of estrogenic hormones and their glucuronides in surface water and waste water in The Netherlands. Science of the Total Environment 225, 101-108

Bhandari RK, Deem SL, Holliday DK, Jandegian CM, Kassotis CD, Nagel SC, Tillitt DE, Saal FSV, Rosenfeld CS (2015): Effects of the environmental estrogenic contaminants bisphenol A and 17 alpha-ethinyl estradiol on sexual development and adult behaviors in aquatic wildlife species. Gen Comp Endocr 214, 195-219

Cargouet M, Perdiz D, Mouatassim-Souali A, Tamisier-Karolak S, Levi Y (2004): Assessment of river contamination by estrogenic compounds in Paris area (France). Science of the Total Environment 324, 55-66

Chitescu CL, Kaklamanos G, Nicolau Al, Stolker AA (2015): High sensitive multiresidue analysis of pharmaceuticals and antifungals in surface water using U-HPLC-Q-Exactive Orbitrap HRMS. Application to the Danube river basin on the Romanian territory. The Science of the total environment 532, 501-11

Costa DDM, Neto FF, Costa MDM, Morais RN, Garcia JRE, Esquivel BM, Ribeiro CAO (2010): Vitellogenesis and other physiological responses induced by 17 -beta-estradiol in males of freshwater fish Rhamdia quelen. Comp Biochem Phys C 151, 248-257

Desbrow C, Routledge EJ, Brighty GC, Sumpter JP, Waldock M (1998): Identification of estrogenic chemicals in STW effluent. 1. Chemical fractionation and in vitro biological screening. Environ Sci Technol 32, 1549-1558

European Parliament (2008): Directive, 2008/105/EC O.J. L 348/84 (16 December)

European Parliament (2013): Directive, 2013/39/EU O.J. L 229/1 (24 August)

European Parliament (2015): Comission Implementing Decision, 2015/495/EU O.J. L 78 (20 March)

Faludi T, Balogh C, Serfozo Z, Molnar-Perl I (2015): Analysis of phenolic compounds in the dissolved and suspended phases of Lake Balaton water by gas chromatography-tandem mass spectrometry. Environ Sci Pollut R 22, 11966-11974

Franke AA, Custer LJ, Morimoto Y, Nordt FJ, Maskarinec G (2011): Analysis of urinary estrogens, their oxidized metabolites, and other endogenous steroids by benchtop orbitrap LCMS versus traditional quadrupole GCMS. Anal Bioanal Chem 401, 1319-1330

Garriz A, Menendez-Helman RJ, Miranda LA (2015): Effects of estradiol and ethinylestradiol on sperm quality, fertilization, and embryo-larval survival of pejerrey fish (Odontesthes bonariensis). Aquatic toxicology 167, 191-199

Gorga M, Petrovic M, Barcelo D (2013): Multi-residue analytical method for the determination of endocrine disruptors and related compounds in river and waste water using dual column liquid chromatography switching system coupled to mass spectrometry. J Chromatogr A 1295, 5766

Hallgren S, Volkova K, Reyhanian N, Olsen KH, Hallstrom IP (2011): Anxiogenic behaviour induced by 17alpha-ethynylestradiol in male guppies (Poecilia reticulata). Fish physiology and biochemistry $37,911-8$

Huang B, Sun W, Li X, Liu J, Li Q, Wang R, Pan X (2015): Effects and bioaccumulation of 17betaestradiol and 17alpha-ethynylestradiol following long-term exposure in crucian carp. Ecotoxicology and environmental safety 112, 169-76

Ismail Ahmad SZZ, Usuki Y., Kitajima S., Arizono, K. (2007): The level of 17ß-estradiol in aquatic environments around Klang Valley. Malaysian Applied Biology 36, 85-87

James MO (2011): Steroid catabolism in marine and freshwater fish. J Steroid Biochem 127, 167-175

Janer G, Lavado R, Thibaut R, Porte C (2005): Effects of 17beta-estradiol exposure in the mussel Mytilus galloprovincialis: a possible regulating role for steroid acyltransferases. Aquatic toxicology $75,32-42$ 
Jarosova B, Blaha L, Giesy JP, Hilscherova K (2014): What level of estrogenic activity determined by in vitro assays in municipal waste waters can be considered as safe? Environment international 64, 98-109

Ke YY, Bertin J, Gonthier R, Simard JN, Labrie F (2014): A sensitive, simple and robust LC-MS/MS method for the simultaneous quantification of seven androgen- and estrogen-related steroids in postmenopausal serum. J Steroid Biochem 144, 523-534

Ketha H, Girtman A, Singh RJ (2015): Estradiol assays - The path ahead. Steroids 99, 39-44

Kim SH, Tian Q, Fang JS, Sung SW (2015): Removal of 17-beta estradiol in water by sonolysis. Int Biodeter Biodegr 102, 11-14

Koal T, Schmiederer D, Pham-Tuan H, Rohring C, Rauh M (2012): Standardized LC-MS/MS based steroid hormone profile-analysis. J Steroid Biochem 129, 129-138

Kuch HM, Ballschmiter K (2001): Determination of endocrine-disrupting phenolic compounds and estrogens in surface and drinking water by HRGC-(NCl)-MS in the picogram per liter range. Environ Sci Technol 35, 3201-3206

Kuster M, López de Alda MJ, Hernando MD, Petrovic M, Martín-Alonso J, Barceló D (2008): Analysis and Occurrence of Pharmaceuticals, Estrogens, Progestogens and Polar Pesticides in Sewage Treatment Plant Effluents, River Water and Drinking Water in the Llobregat River Basin (Barcelona, Spain). Journal of Hydrology 358, 112-123

LaFleur AD, Schug KA (2011): A review of separation methods for the determination of estrogens and plastics-derived estrogen mimics from aqueous systems. Anal Chim Acta 696, 6-26

Li XN, Franke AA (2015): Improved profiling of estrogen metabolites by orbitrap LC/MS. Steroids 99, 84-90

Liu JL, Wang RM, Huang B, Lin C, Wang Y, Pan XJ (2011a): Distribution and bioaccumulation of steroidal and phenolic endocrine disrupting chemicals in wild fish species from Dianchi Lake, China. Environ Pollut 159, 2815-2822

Liu S, Ying GG, Zhao JL, Chen F, Yang B, Zhou LJ, Lai HJ (2011b): Trace analysis of 28 steroids in surface water, wastewater and sludge samples by rapid resolution liquid chromatographyelectrospray ionization tandem mass spectrometry. J Chromatogr A 1218, 1367-1378

Liu Y, Guan YT, Mizuno T, Tsuno H, Zhu WP (2009): A Pretreatment Method for GC-MS Determination of Endocrine Disrupting Chemicals in Mollusk Tissues. Chromatographia 69, 65-71

Loos R, Locoro G, Contini S (2010): Occurrence of polar organic contaminants in the dissolved water phase of the Danube River and its major tributaries using SPE-LC-MS2 analysis. Water Res 44, 2325-2335

Martyniuk CJ, Gerrie ER, Popesku JT, Ekker M, Trudeau VL (2007): Microarray analysis in the zebrafish (Danio rerio) liver and telencephalon after exposure to low concentration of 17alphaethinylestradiol. Aquatic toxicology 84, 38-49

Matozzo V, Gagne F, Marin MG, Ricciardi F, Blaise C (2008): Vitellogenin as a biomarker of exposure to estrogenic compounds in aquatic invertebrates: A review. Environment international 34, 531-545

Moraes FC, Rossi B, Donatoni MC, de Oliveira KT, Pereira EC (2015): Sensitive determination of 17 beta-estradiol in river water using a graphene based electrochemical sensor. Anal Chim Acta $881,37-43$

Nie MH, Yan CX, Dong WB, Liu M, Zhou JL, Yang Y (2015): Occurrence, distribution and risk assessment of estrogens in surface water, suspended particulate matter, and sediments of the Yangtze Estuary. Chemosphere 127, 109-116

Patrolecco L, Capri S, Ademollo N (2015): Occurrence of selected pharmaceuticals in the principal sewage treatment plants in Rome (Italy) and in the receiving surface waters. Environ Sci Pollut R 22, 5864-5876

Pojana G, Gomiero A, Jonkers N, Marcomini A (2007): Natural and synthetic endocrine disrupting compounds (EDCs) in water, sediment and biota of a coastal lagoon. Environment international 33, 929-936

Popescu IL, Aboul-Enein H, Tanase IG, Ghica I, Bala C (2008): Validation of a Quantitative Method Determination of Estradiol in Pharmaceutical Products using UV-Vis Molecular Absorption Spectrometry. Anal Lett 41, 3272-3296

Reyhanian N, Volkova K, Hallgren S, Bollner T, Olsson PE, Olsen H, Hallstrom IP (2011): 17alphaEthinyl estradiol affects anxiety and shoaling behavior in adult male zebra fish (Danio rerio). Aquatic toxicology $105,41-8$ 
Ripolles C, Ibanez M, Sancho JV, Lopez FJ, Hernandez F (2014): Determination of 17 beta-estradiol and 17 alpha-ethinylestradiol in water at sub-ppt levels by liquid chromatography coupled to tandem mass spectrometry. Anal Methods-Uk 6, 5028-5037

Robinson BJ, Hellou J (2009): Biodegradation of endocrine disrupting compounds in harbour seawater and sediments. Science of the Total Environment 407, 5713-5718

Robles TA (2010): Use of Oral Contraceptives, Decision Making in Medicine (Third Edition), pp. 616619

Sebok A, Vasanits-Zsigrai A, Helenkar A, Zaray G, Molnar-Perl I (2009): Multiresidue analysis of pollutants as their trimethylsilyl derivatives, by gas chromatography-mass spectrometry. $J$ Chromatogr A 1216, 2288-2301

Shinichi Miyagawa TS, Taisen Iguchi (2016): Handbook of Hormones

Skotnicka-Pitak J, Garcia EM, Pitak M, Aga DS (2008): Identification of the transformation products of 17 alpha-ethinylestradiol and 17 beta-estradiol by mass spectrometry and other instrumental techniques. Trac-Trend Anal Chem 27, 1036-1052

Tan Y, Wei TX (2015): Detection of 17 beta-estradiol in water samples by a novel double-layer molecularly imprinted film-based biosensor. Talanta 141, 279-287

Torres NH, Aguiar MM, Ferreira LFR, Americo JHP, Machado AM, Cavalcanti EB, Tornisielo VL (2015): Detection of hormones in surface and drinking water in Brazil by LC-ESI-MS/MS and ecotoxicological assessment with Daphnia magna. Environ Monit Assess 187

Williams RJ, Johnson AC, Smith JJL, Kanda R (2003): Steroid estrogens profiles along river stretches arising from sewage treatment works discharges. Environ Sci Technol 37, 1744-1750

Wise A, O'Brien K, Woodruff T (2011): Are Oral Contraceptives a Significant Contributor to the Estrogenicity of Drinking Water? Environ Sci Technol 45, 51-60

Xu L, Spink DC (2008): Analysis of steroidal estrogens as pyridine-3-sulfonyl derivatives by liquid chromatography electrospray tandem mass spectrometry. Anal Biochem 375, 105-114

Xu X, Akki S, Silverman S, Werth CJ (2013): Detection of 17b-estradiol in drinking water sources using DNA aptamer-based electrochemical detection. Abstr Pap Am Chem S 245

Yan ZH, Lu GH, Liu JC, Jin SG (2012): An integrated assessment of estrogenic contamination and feminization risk in fish in Taihu Lake, China. Ecotoxicology and environmental safety 84, 334340

Zou YM, Zhang Z, Shao XL, Chen Y, Wu XY, Yang LQ, Zhu JJ, Zhang DM (2014): Hollow-fibersupported liquid-phase microextraction using an ionic liquid as the extractant for the preconcentration of bisphenol A, 17-beta-estradiol, estrone and diethylstilbestrol from water samples with HPLC detection. Water Sci Technol 69, 1028-1035 
List of figure captions:

Fig. 1 Derivatization reactions of E2 (A) and EE2 (B) with dansyl-chloride Fig. 2 SIM mode chromatogram obtained from derivatised standards $100 \mathrm{pg}$ on column.

Dansyl-E2 at $13.13 \mathrm{~min}(\mathrm{~m} / \mathrm{z}=506.24)$ and dansyl-EE2 at $13.69 \mathrm{~min}(\mathrm{~m} / \mathrm{z} 530.24)$

Fig. 3 SIM mode chromatogram obtained from sample No. 5 (Hévíz-Páhoki canal)

Dansyl-E2 at $13.14 \mathrm{~min}(\mathrm{~m} / \mathrm{z}=506.24)$ and dansyl-EE2 at $13.70 \mathrm{~min}(\mathrm{~m} / \mathrm{z} 530.24)$

Suppl. Fig. 1 Map of sampling sites GPS coordinates can be found in Table 1 and Table 2

Suppl. Fig. 2 Blank chromatograms 